\title{
THE COPENHAGEN NECK FUNCTIONAL DISABILITY SCALE - CNFDS: TRANSLATION AND CULTURAL ADAPTATION TO BRAZILIAN PORTUGUESE
}

\author{
Flávia Azevedo Righi Badaró ${ }^{1}$, Rubens Corrêa Araújoㄹ, Mara Behlau³
}

DOI: dx.doi.org/10.7322/jhdg.88965

\begin{abstract}
Introduction: the Danish questionnaire entitled The Copenhagen Neck Functional Disability Scale(CNFDS) is a tool for self-assessment of cervical complaints, originally developed in English, of which there is, so far, no translation into Brazilian Portuguese. The process involvedin this researchproved to be relevant for the exploration of the questionnaire and the realization of adjustments necessary for it to be functionaT and applicable in Portuguese Language and Brazilian Culture settings. Thus, once this has been carried out, many health professionals will benefit from this version in their clinical practice. Objective: To perform the translation and cultural adaptation to Brazilian Portuguese of the Escala funcional de incapacidade do pescoço de Copenhagen (The Copenhagen Neck Functional Disability Scale - CNFDS). Methods: The questionnaire was translated into Brazilian Portuguese by two bilingual, Brazilian physiotherapists who were aware of the objective of this research. The back-translation was performed by a third person, a Brazilian, bilingual English teacher, who had not participated in the previous step. After comparing the resulting translations, a single translated version was produced named the Escala Funcional de Incapacidade do Pescoço de Copenhagen (EFIPC) and in each question the option "not applicable" was added to the answer key. During the translation and cultural adaptation process there were no changes and/or eliminations of any questions. Result: The composition of the Escala Funcional de Incapacidade do Pescoço de Copenhagen reflects the original English version, with a total of 15 questions, with the questions numbered 1 to 5 presenting a positive direction response (a "yes" answer indicates good cervical condition), and questions numbered 6 to 15 presenting a negative direction response (a "yes" answer indicates poor cervical condition). Conclusion: The process involved in this research allowed the achievement of thedesired goal, and thus it was possible totranslate and culturally adapt to Brazilian Portuguese the content of the CNFDS questionnaire, giving riseto the Escala funcional de incapacidade do pescoço de Copenhagen.
\end{abstract}

Key words: neck pain, disability, physiotherapy, translation.

\section{INTRODUCTION}

Pain in the neck (cervical pain) may have different origins, among them postural changes, such as mechanical trauma, joint compressions and rectifications. It is understood that the term cervical pain does not refer to a disease itself, but rather to a symptom or a manifestation of a painful muscular disorder ${ }^{1}$. Cervical pain usually has multifactorial clinical aspects, since it may involve individual risk factors (either physical or emotional characteristics), or be related to ergonomics and work activities ${ }^{1,2}$.

The different dimensions of chronic spinal pain require extensive description of the entity presented in the disease, which, according to Waddell, include principally "being compromised due to pain, physical impairment and disability" 3,4 .

Well delineated by evaluation instruments (for example, by standardized questionnaires), cervical pain is very common in the general population ${ }^{3,5,6}$. In Western countries, pain in the neck is reported as a major cause of long-term sick leave and labor pensions ${ }^{7}$. Persistent and debilitating neck pain resulting from car accidents are also common ${ }^{3,8}$.

Therefore it is difficult to define accurately, at a single stroke, the prevalence of cervical pain. In three recent national studies the prevalence of

1 Bacharel em Fonoaudiologia e Fisioterapia.

2 Doutor. Professor.Departamento de Fisioterapia, Universidade de Taubaté - UNITAU - Taubaté (SP), Brasil.

3 Doutora. Professora de pós-graduação do Departamento de Fonoaudiologia da Universidade Federal de São Paulo (UNIFESP), São Paulo (SP), Brasil e do Instituto Superior de Ensino em Comunicação (ISEC) / Centro de Estudos da Voz (CEV), São Paulo (SP), Brasil.

Corresponding author: flabadaro@hotmail.com

Suggested citation: Badaró FAR, Araújo RC, Behlau M. The Copenhagen neck functional disability scale - CNFDS: translation and cultural adaptation to brazilian portuguese. 24(3): 304-312

Manuscript submitted Jun 22 2014, accepted for publication Oct 282014. 
cervical pain was assessed in the overall Brazilian population (without limitations or other specifications to the group) $)^{1,2,9}$ :

Machado ${ }^{1}$ stated that cervical pain affects $30 \%$ of men and $43 \%$ of women at some point in their lives.

Silva ${ }^{9}$ found that cervical pain affects an average of $12 \%$ to $34 \%$ of the adult population at some stage of their life, with the highest incidence in females, causing some type of impairment in their work activities.

Antônio ${ }^{2}$ reported that the prevalence of cervical pain is estimated at $29 \%$ in men and $40 \%$ in women, these numbers may be even higher when evaluating selected populations according to activities performed at work.

Fonseca ${ }^{10}$ aimed to map out the general characteristics of patients in Florianópolis - SC who presented previously diagnosed chronic cervical pain (in a study performed in private clinics, the Association of Municipal Rehabilitation and the outpatient clinic of the University Hospital) and found that the age group with the highest incidence of cervical pain was between $45-65$ years and it was more common in females, at $74 \%$.

The high percentages of prevalence of cervical pain still appear even in studies in which the research population is more specific ${ }^{10-14}$ :

In research carried out with college students from the south of Brazil it was seen that $49.7 \%$ of this specific population complained of having experienced cervical pain during the previous 12 months ${ }^{11}$.

When studies are performed with samples selected according to occupational activity, cervical pain is also present. In dental surgeons this prevalence may be significant, as seen by Santos Filho ${ }^{12}$, in a study consisting of dental surgeons in Belo Horizonte - MG, where a $20 \%$ prevalence of cervical pain was found.

Cervical pain can also cause other types of damage to an individual, such as alterations and/ or compensation in the musculoskeletal system, for example the shoulder girdle, which may cause associated tensions that influence the position of the head and jaw, possibly developing into a framework of temporomandibular dysfunction, as seen in a study by Gorreriet al. ${ }^{15}$ where $100 \%$ of the individuals surveyed and patients with cervical pain, presented temporomandibular dysfunction.

The proximity of the structures in question (bone, muscle and cartilage) raises the possibility that imbalances in the cervical muscles may somehow be related to certain types of dysphonia, which could be so named by the association of laryngeal sensation with vocal complaints ${ }^{16}$. If cervical pain is present among the complaints of a dysphonia patient it will probably be a limiting factor to treatment, as this sometimes involves the use of laryngeal manipulation and postural changes to the head $^{17}$.

As these aforementioned studies demonstrate succinctly, complaints of cervical pain are so common in clinical practice that they can currently be considered a public health problem, prevalent in various specialties among health professionals. ${ }^{11}$
However, the definition and understanding of public health and its role has changed continuously over time, often affected by current events and the perceived needs of health protection, as well as disease and its prevention ${ }^{18}$. The role of public health has evolved with the advancement of civilization and the reduced threat of common infectious diseases, having to solve problems associated with behavioral risks and those related to new technology, including trauma injuries resulting from accidents involving transportation. These adaptations over time have meant that the very definition of health has undergone major revisions, since it was initially seen as merely the "absence of disease" and now has a much broader and more insightful concept which considers the capacity of people to adapt, respond to and manage challenges and changes in life. ${ }^{18}$

To measure the impact that cervical pain can have on an individual as well as the limitations generated by it, several questionnaires and evaluation scales have been developed, often in the English language ${ }^{19}$, such as the Neck Disability Index $(N D I)^{20}$, the Neck Pain and Disability Scale (NPDS) ${ }^{21}$, the Cervical Spine Outcomes Questionnaire $(\mathrm{CSOQ})^{22}$ and the North wick Park Neck Pain Questionnaire (NPK) ${ }^{23}$.

Scales and self-assessment questionnaires, besides their scientific importance, can guide clinical practice ${ }^{3,24-26}$. Despite the recognized practicality and usefulness of these questionnaires, the procedures related to their creation and development have only recently been standardized with the development of the Scientific Advisory Committee of Medical Out comes Trust ${ }^{27}$ whose main purpose is to select standardized criteria for the development of quality of life self-assessment protocols and adjustments/adaptations in languages other than the original.

For this purpose, these materials need to be translated and adapted according to specific international rules and thus have their measured properties demonstrated within a specific cultural context ${ }^{27}$. Thus, a questionnaire that requires validation must follow several steps and certain criteria, initially being carefully translated and culturally adapted, as a simple literal translation might exclude specific cultural and social contexts. This is because the process of translating an instrument may be inadequate due to semantic, conceptual and cultural differences between different languages ${ }^{28}$.

To this end, what is commonly used and recommended is the translation of the scale items, followed by a back translation conducted by an independent translator. In this method, a bilingual individual translates from the source language to the target language and then another individual, who has not had access to the original instrument, translates it back to the source language. Following this, comparisons are made between the translation and back-translation to identify possible discrepancies between the source and the target, followed by considerations by the bilingual translator to identify potential issues with cultural equivalence, aiming to obtain a corresponding version ${ }^{29}$. 
The questionnaire should then be tested to ensure its suitability for the focus population, language and culture, following international rules for linguistic adaptation and cultural equivalence, validity, reproducibility, sensitivity, and reliability $27,30,31$.

Considering these aspects, The Copenhagen Neck Functional Disability Scale (CNFDS) is a clinical evaluation tool that accurately reflects the patient's perception regarding their functionality against the backdrop of cervical pain ${ }^{3}$, being able to help direct clinical perspectives $3,19,32,33$.

The CNFDS is a self-assessment questionnaire, which makes its application easier as it can be executed directly by the patient, a fact which brings some features and advantages, as it lessens the chance of misinterpretation by the evaluator; is easily accessible; does not contain specific technical terminology, enabling a greater understanding by the patient responding to it and it can be completed without the presence and lead of a researcher ${ }^{3}$.

The CNFDS (original instrument for validation) is the only version translated into English, among cervical specific questionnaires ${ }^{19}$. It has already been translated into French ${ }^{32}$, Polish ${ }^{33}$ and Turkish ${ }^{34}$ but not to Brazilian Portuguese.

As it is a frequently used tool for selfassessment of cervical disability, ${ }^{24-26}$ with excellent practicality and reliability (demonstrated during validation $)^{3}$, it was chosen for this study.

Thus, the translation and adaptation of the CNFDS to Brazilian Portuguese brings the possibility of a further tool for assessing the effect and impact that cervical dysfunction can have on a patient's life. Being easy and simple to apply, it can be used not only by physical therapists but by other health professionals who deal with complaints related to the cervical region, such as dysphonia patients treated by speech therapists. Therefore, the aim of this study was to provide the translation and adaptation of the Copenhagen Neck Functional Disability Scale (CNFDS) to Brazilian Portuguese.

\section{METHODS}

The questionnaire chosen to be translated, which is the focus of this research was the Copenhagen Neck Functional Disability Scale (CNFDS $)^{3}$. The translation was performed together with the respective cultural adaptation of the CNFDS through cultural and linguistic adaptation of the instrument ${ }^{3,19}$, with the version entitled Escala Funcional de Incapacidade do Pescoço de Copenhagen (EFIPC).

This process was initially performed by two bilingual Brazilian physical therapists and one speech therapist who were aware of the objective of this study and performed the conceptual translation, avoiding the literal use of words or phrases. Following this, the two translations were compiled into a third, by consensus. The back translation was carried out by a third person, an English teacher and speech pathologist with no knowledge of the questionnaire in the original
English version and who had not participated in the previous step. The translation and respective back translation were duly compared with each other and the original questionnaire, and the differences found were analyzed and discussed by a group of three physiotherapists active in the field of orthopedics and fluent in English who made the necessary adjustments by consensus, producing a final questionnaire, entitled Escala Funcional de Incapacidade do Pescoço de Copenhagen - EFIPC.

The option "not applicable" was added to the answer key for every one of the questions in the protocol, giving four possible answers in this phase of the study (yes, sometimes, no, and "not applicable"). This addition was proposed in order to identify questions that were not understood by or were inappropriate to the population, for subsequent modification or elimination in the future Brazilian Portuguese version.

The population chosen to participate in this study of cultural equivalence was individuals who, at that time, were attending physical therapy for cervical pain in a Higher Education Institution of Physiotherapy (Department of Orthopaedic Physiotherapy, Clinical School of Physiotherapy, University of Taubaté). The age group distribution was $18-65$ years with a mean age of 35.86 years. The number of participants who met the study profile and were surveyed was 15 subjects, 3 men and 12 women.

The subjects were adult patients of both sexes with complaints of cervical pain without having other significant orthopedic impairments. (These participants were selected regardless of whether they had been previously treated sequentially or not, in a clinical school, in the public sector or in private practice).

The presence of complaints of cervical pain of any kind or degree was considered as the inclusion criteria, whether or not the patients had already been treated in other institutions.

The following were considered as exclusion criteria: a lack of interest or unavailability to participate in the research, the presence of neurological, cognitive and/or psychiatric disorders which would make it impossible to implement the protocol, a lack of understanding of the instructions and/or illiteracy.

The study was approved by the Committee for Ethics in Research, University of Taubaté (UNITAU) (269/12). All participants signed a Free and Informed Consent Form (FIC).

\section{RESULTS}

During the translation and cultural adaptation process there were no modifications and/or removal of any questions. The final composition of the translation of the EFIPC (Table 1), after linguistic and cultural adaptation, consisted of 15 interrogative questions, 5 with positive direction (questions 1 to 5; in which a "yes" answer indicated good function) and 10 with negative direction (questions 6 to 15, in which a "yes" answer indicated poor function), in exact accordance with the original questionnaire. . 
The final translated version of the instrument The Copenhagen Neck Functional Disability Scale was left with a framework of questions, translated as follows:

Table 1: Escala Funcional de Incapacidade do Pescoço de Copenhagen (Final version translated from the original The Copenhagen Neck Functional Disability Scale; by Jordan A, Manniche C, Mosdal C \& Hindsberger $\mathrm{C}^{3}$ :

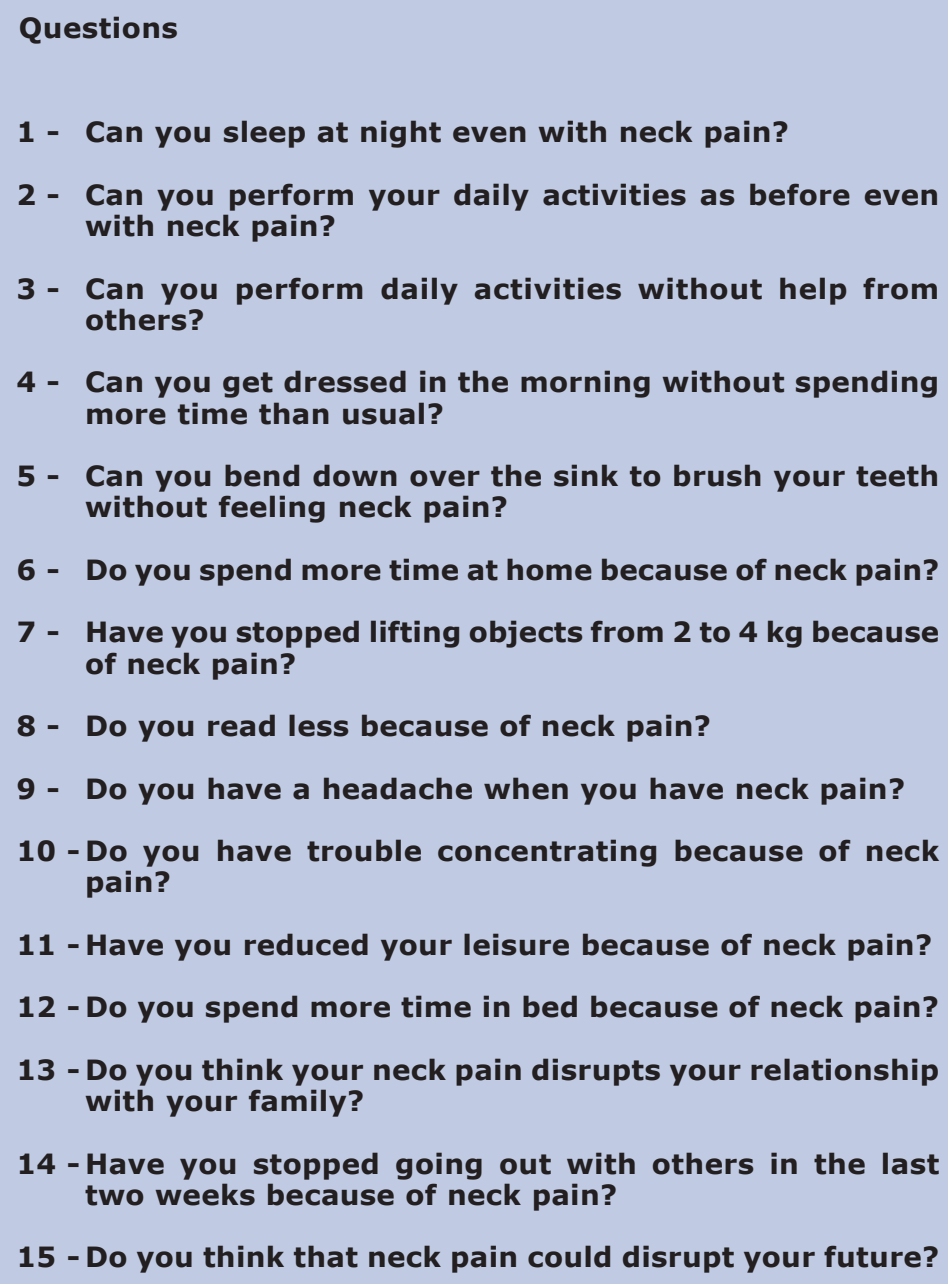

2 - Can you perform your daily activities as before even with neck pain?

3 - Can you perform daily activities without help from others?

4 - Can you get dressed in the morning without spending more time than usual?

5 - Can you bend down over the sink to brush your teeth without feeling neck pain?

6 - Do you spend more time at home because of neck pain?

7 - Have you stopped lifting objects from 2 to $4 \mathrm{~kg}$ because of neck pain?

8 - Do you read less because of neck pain?

9 - Do you have a headache when you have neck pain?

10 - Do you have trouble concentrating because of neck pain?

11 - Have you reduced your leisure because of neck pain?

12 - Do you spend more time in bed because of neck pain?

13 - Do you think your neck pain disrupts your relationship with your family?

14 - Have you stopped going out with others in the last two weeks because of neck pain?

15 - Do you think that neck pain could disrupt your future?

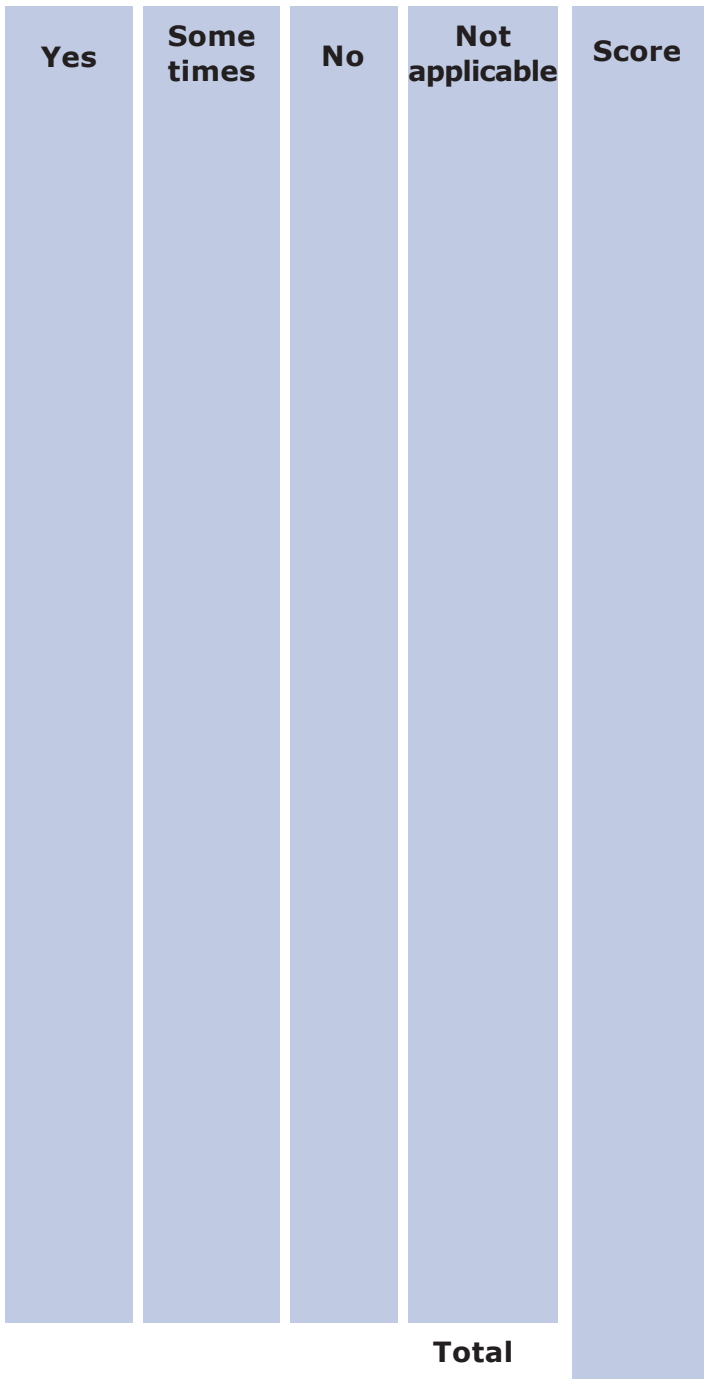

The scoring of this scale was also calculated from the original CNFDS questionnaire ${ }^{3}$, taking into account the two possible directions of responses. As can be seen in Table 2, the questions numbered 1 to 5 are questions of positive direction, i.e., a "yes" answer indicates good cervical condition and questions numbered 6 to 15 are questions of a negative direction, so a "yes" answer indicates poor cervical condition. Thus, the maximum possible score is 30 points, and the minimum 0 ; the higher the score, the greater the dysfunction ${ }^{3}$.

Table 2: Classification of the scores for each question of the Escala Funcional de Incapacidade do Pescoço de Copenhagen, according to the positive/negative direction of the responses given by the patients:

$\begin{array}{lcc}\text { Responses } & \begin{array}{c}\text { Points for positive direction } \\ \text { (question numbers 1 to 5) }\end{array} & \begin{array}{c}\text { Points for negative direction } \\ \text { (question numbers 6 to 15) }\end{array} \\ \text { YES } & 0 & 2 \\ \text { SOMETIMES } & 1 & 0 \\ \text { NO } & 2 & -\end{array}$


The classifications of dysfunction, according o the number of points obtained in the total score, corresponding to the original article ${ }^{3}$.

1 to 3 points $=$ minimal disability;

4 to 8 points = mild disability;

9 to 14 points $=$ mild to moderate disability; 15 to 20 points $=$ moderate disability;
21 to 26 points $=$ moderate to severe disability;

27 to 30 points $=$ severe disability.

The answers given by the 15 participants were grouped for each question respectively, according to their evaluations and the results are presented in Table 3.

Table 3: Escala Funcional de Incapacidade do Pescoço de Copenhagen with the number of responses obtained for each question from the 15 participating subjects:

\begin{tabular}{|c|c|c|c|c|c|}
\hline Questions & Yes & $\begin{array}{l}\text { Some } \\
\text { times }\end{array}$ & No & $\begin{array}{c}\text { Not } \\
\text { applicable }\end{array}$ & Score \\
\hline 1 - Can you sleep at night even with neck pain? & 2 & 9 & 4 & 0 & \\
\hline $\begin{array}{l}2 \text { - Can you perform your daily activities as before even with } \\
\text { neck pain? }\end{array}$ & 4 & 5 & 6 & 0 & \\
\hline 3 - Can you perform daily activities without help from others? & 13 & 2 & 0 & 0 & \\
\hline $\begin{array}{l}4 \text { - Can you get dressed in the morning without spending more } \\
\text { time than usual? }\end{array}$ & 11 & 2 & 2 & 0 & \\
\hline $\begin{array}{l}5 \text { - Can you bend down over the sink to brush your teeth without } \\
\text { feeling neck pain? }\end{array}$ & 2 & 8 & 5 & 0 & \\
\hline 6 - Do you spend more time at home because of neck pain? & 1 & 6 & 8 & 0 & \\
\hline $\begin{array}{l}7 \text { - Have you stopped lifting objects from } 2 \text { to } 4 \mathrm{~kg} \text { because of } \\
\text { neck pain? }\end{array}$ & 6 & 5 & 4 & 0 & \\
\hline 8 - Do you read less because of neck pain? & 7 & 3 & 4 & 1 & \\
\hline 9 - Do you have a headache when you have neck pain? & 12 & 1 & 2 & 0 & \\
\hline 10- Do you have trouble concentrating because of neck pain? & 13 & 2 & 0 & 0 & \\
\hline 11- Have you reduced your leisure because of neck pain? & 6 & 3 & 6 & 0 & \\
\hline 12- Do you spend more time in bed because of neck pain? & 3 & 3 & 9 & 0 & \\
\hline $\begin{array}{l}\text { 13- Do you think your neck pain disrupts your relationship with } \\
\text { your family? }\end{array}$ & 5 & 4 & 6 & 0 & \\
\hline $\begin{array}{l}\text { 14- Have you stopped going out with others in the last two weeks } \\
\text { because of neck pain? }\end{array}$ & 4 & 3 & 8 & 0 & \\
\hline 15 - Do you think that neck pain could disrupt your future? & 15 & 0 & 0 & 0 & \\
\hline
\end{tabular}

From the responses it can be seen that the translations, together with the respective cultural adaptation to Brazilian Portuguese appear to have been effective and achieved the main purpose, suggested by the low response rate to "not applicable"; only one case out of a possible 225 (= $0.44 \%$ ), from a subject who reported not having the habit or the need for reading in their profession (auxiliary cleaner).

The average total score obtained from the responses of the 15 patients in this study was 16.26 points, whereas the maximum score was 26 points - in one subject ( $6.66 \%$ of the surveyed subjects) - indicating moderate to severe disability and the minimum score was 10 - mild to moderate disability - also in one subject $(6.66 \%)$.

\section{DISCUSSION}

To support clinical performance, professionals in the field of health rely on a number of techniques available to facilitate their clinical rationale, thus aiding their assessment, diagnosis and treatment. Evaluation questionnaires translated and culturally adapted to the local language and easy to use and apply by the therapist are of great importance for clinical practice, therefore, these instruments should be more widely explored and used.

The research proposal presented in this study took as a starting point the cervical self-assessment questionnaire, The Copenhagen Neck Functional Disability Scale ${ }^{3}$, which was translated and culturally adapted to Brazilian Portuguese, whilst keeping its 
functionality and character unchanged. The procedures for this language change and the cultural adaptation followed the standards established for this step, by the Scientific Advisory Committee of Medical Outcomes Trust ${ }^{27}$, whose main purpose is to select standardized criteria for the development of protocols of self-assessment of quality of life and adjustments/adaptations to languages other than the original. Translations of questionnaires like this can be seen as an additional possible assessment tool to complement clinical practice.

Cruciani et al., in a study performed on the conceptual equivalence and the items and semantics of specific questionnaires ${ }^{35}$, cited references pointing out that, when proposing the adaptation of a questionnaire, it is essential and necessary to consider the differences in each society. Furthermore, the questionnaire should be, whilst maintaining the features of the original, written in simple and clear language, obtaining equivalence with respect to the cultural concepts in question. Regarding the semantic equivalence, these authors further point out that the translated and adapted questionnaire must be free of ambiguity and use common expressions, in this case, in accordance with the Brazilian culture. There fore, all of these conditions appear to have been met in the present study.

According to the results obtained in the responses from the 15 subjects who participated in the process of translation and adaptation of the Brazilian Portuguese EFIPC, the findings show similarities to the original article and other translations in the literature. Three translations were performed, from which the back translation was obtained, used to achieve the final version. The fact that three initial translations were performed helped in making decisions on appropriate terms to be used in the final version, aiming to increase the trustworthiness of the document according to the linguistic structure of Brazilian Portuguese. Cruciani et al. reinforced the importance of two or more translations of the original questionnaire being made for a fair adaptation in this process ${ }^{35}$.

No difficulties were encountered by the researcher in the stage of applying the EFIPC to the research subjects. In fact, all patients who met the inclusion criteria and were invited to participate agreed to do so without restriction. In addition, they demonstrated good understanding of the questionnaire, without raising doubts as to understanding the contents, indicating an efficient translation to the desired language, as well as the easy applicability of the questionnaire.

In a systematic review conducted in 2011 on the measurement properties of translated versions of specific cervical questionnaires, Schellingerhout et al. ${ }^{36}$ analyzed the average time taken to complete the original version of the questionnaire, the CNFDS, which was 6.8 minutes. Although in this research, measuring the time taken to complete the EFIPC was not an objective, according to the observations of the researcher, the time taken appeared to be similar.

As in the original document, the CNFDS, there was a tendency for women to have higher scores than men within the same classification group of disability, but not when considering the overall score of the questionnaire. One possibility that may seek to understand this difference in scores between the genders is the fact that women, in general, present a greater effort to generate force than men.

Comparing the scores obtained with those in the literature, it was found that in the translation of the CNFDS into Polish ${ }^{33}$ an average score of 17.7 points was obtained, with $3.3 \%$ of the patients achieving the minimum score and $1.7 \%$ obtaining the maximum score. The same questionnaire was translated into French, with only one version of translation and cultural adaptation ${ }^{32}$. Comparing these two versions, the French version obtained good or regular correlation with the total score in all items and the Polish version obtained very good correlation with the overall result in almost all items ${ }^{34}$.

In addition to these French and Polish versions translated from the original English, the CNFDS was also translated and culturally adapted into the Turkish language, in all cases without alterations or changes in the original structure ${ }^{32,33}$. Schellingerhout et al. ${ }^{36}$ correlated the French and Turkish versions of the CNFDS and found that both obtained only sensitivity in the translation process as the property of the relevant measure.

The translation, together with the adaptation in terms of the language according to the culture and language use in the country, is the first stage of the validation process of protocols, since, from this stage, the rest of the process is implemented. Thus, it is through cultural adaptation that a translated questionnaire can be applied to the population of the language in question ${ }^{19}$. Given the scarcity of other translated versions of the CNFDS, the adapted translation to Brazilian Portuguese in this research contributes to the usability of this important international questionnaire in one more language, maintaining its characteristic as an effective tool for clinical use, now properly translated into the Brazilian Portuguese language.

In research related to cervical pain, the NDI (Neck Disability Index) questionnaire $20,37-40$ is often used as a functional evaluation tool in addition to others such as the CSOQ (Cervical Spine Outcomes Questionnaire) ${ }^{22}$ or the NPK (Northwick Park Neck Pain Questionnaire)23,41. These, however, are instruments for patient assessment which are applied by an evaluator, and not directly answered by the patients. Therefore, in this study, the CNFDS was chosen.

The realization of this adapted translation of the CNFDS paves the way for a future validation process of the EFIPC to Brazilian Portuguese, which will enable its reliable use in clinical and scientific practice, aiding the selection of common findings in patients with cervical complaints through a specific and culturally adapted protocol.

Being a self-assessment questionnaire which is easy to apply and does not depend on application by an evaluator, the EFIPC can be used broadly, so that health professionals can apply it to their patients, and thus better understand the extent of their disorder, specifically regarding the impact that cervical pain brings to their activities of daily life 
and the consequent constraints on the execution of even simple and mundane actions in the routine of the patient. Thus, having this assessment instrument translated and culturally adapted to Brazilian Portuguese, increases the possibilities of other health professionals dealing with patients with cervical problems, to better understand how the restrictions on their functionality, due to cervical pain, may be related and/or contribute in some way to other complaints.

In conclusion, the adapted translation of The Copenhagen Neck Functional Disability Scale, to the Brazilian Portuguese version named the Escala

\section{REFERENCES}

1. Machado JOM, Meija DPM. Acupuntura no tratamento da cervicalgia [homepage na internet]. [acesso em fev 2013]. Disponível: http://portalbiocursos.com.br/artigos/ acupuntura/04.pdf.

2. Viana PB, Benini LV, Vasconcellos C. Programa de ginástica laboral versus desconforto laboral. Coleção Pesquisa em Educação Física. 2011; 10(2): 125-32.

3. Jordan A, Manniche C, Mosdal C, Hindsberger C. The Copenhagen Neck Functional Disability Scale: a study of reliability and validity.] Manipulative PhysiolTher. 1998; 21(8):520527.

4. Waddell G, Main CJ. Assessment of severity in low back disorders.Spine 1984; 9:204-208. DOI: $10.1097 / 00007632-198403000-00012$

5. Kuorinka I, Jonsson B, Kilbom A, Vinterberg $H$, Biering-Sorensen F, Andersson G, Jorgensen K. Standardized Nordic questionnaires for theanalysis of musculoskeletal symptoms. Apud: Jordan A, Manniche C, Mosdal C, Hindsberger $\mathrm{C}$. The Copenhagen Neck Functional Disability Scale: a study of reliability and validity.J Manipulative PhysiolTher. 1998; 21(8):520-527.

6. Bovim G, Schrader H, Sand T. Neck pain in the general population. Spine 1994; 19:13071309. DOI: 10.1097/00007632-19940600000001

7. Rempel DM, Harrison R J, Barnhart S. Workrelated cumulative trauma disorder ofthe upper extremity. JAMA. 1992; 267:838-842. DOI: 10.1001/jama.1992.03480060084035

8. Deans GT, Magalliard JN, Kerr M, Rutherford WH. Neck sprain: a major cause ofdisability following car accidents. Injury.1987; 18:10-12. DOI: $10.1016 / 0020-1383(87) 90375-5$

9. Silva RMV, Lima MS, Costa FH, Silva AC. Efeitos da quiropraxia em pacientes com cervicalgia: revisão sistemática. Rev Dor. São Paulo. 2012; 13(1):71-74. DOI: $10.1590 /$ S180600132012000100013

10. Fonseca KG, Duarte HE, Rosário ARV. Cervicalgia crônica: principais causas e prevenções. In: Arquivos catarinenses de medicina; 2001; 30(3/4):10-14.

11. Mattos GDL, Leite C, Milman LM, Souza LDM, Amaral B, Lüdtke I, et al. Cervicalgia em
Funcional de Incapacidade do Pescoço de Copenhagen was performed within the essential foundations, keeping the conceptual and semantic features of the original, without the need to change or discard any questions.

FARB principal investigator, development of research, collection and analysis of data, writing the article, submission and formalities of the article. ; RCA co-advisor, data analysis, correcting the wording of the article, approval of the final version; $M B$ advisor, development of research, data analysis, correcting the wording of the article, approval of the final version.

estudantes universitários do Sul do Brasil: prevalência e fatores associados. Medicina de reabilitação. São Paulo. 2009; 28(1):15-20.

12. Santos Filho SB, Barreto SB. Atividade ocupacional e prevalência de dor osteomuscular em cirurgiões-dentistas de Belo Horizonte, Minas gerais, Brasil: contribuição ao debate sobre distúrbios osteomusculares relacionados ao trabalho. Cad. Saúde Pública. Rio de Janeiro.2001; 17(1):181-193. DOI: 10.1590/ S0102-311X2001000100019

13. Barbosa ECS, Souza FMB, Cavalcanti AL, Lucas RSCC. Prevalência de distúrbios osteomusculares relacionados ao trabalho em cirurgiõesdentistas de Campina Grande. In: Pesquisas brasileiras odontopediátricas e clínicas integradas. João Pessoa, v. 4, n. 1, p. 19-24, jan./abr. 2004.

14. Borenstein D. Abordagem ao paciente com cervicalgia. In: Imboden, J; Hellmann D; Stone, J. Current: Reumatologia - diagnóstico e tratamento. 2.ed. Dados eletrônicos. Porto Alegre, 2008; (9): 93-100.

15. Gorreri MC, Guimarães EA, Barbosa KVMS, Barbosa GAS, Baraúna MA, Strini PJSA, et al. Relação entre cervicalgia e disfunção temporomandibular. Fisioterapia Brasil. 2008 Jul /Ago; 9(4): 264-268.

16. Menoncin LCM, Jurkievicz AL, Silvério KCA, Camargo, PM, Wolf NMN. Alterações musculares e esqueléticas em mulheres disfônicas. Arq. Int. Otorrinolaringol. / Intl. Arch. Otorhinolaryngol. São Paulo, 2010 out/nov/dez; 14(4):461-466. DOI: $10.1590 / S 1809-48722010000400014$

17. Behlau M (org). Voz: O livro do especialista, volume II. Ed. Revinter, Rio de Janeiro, 2005.

18. Atrash HK, Carpentier R. The envolving role of public health in the delivery health care. Journal of Human Growth and Development, 2012; 22(3): 396-399.

19. Pietrobon R, Coeytaux RR, Carey TS, Richardson WJ, DeVellis RF. Standard scales for measurement of functional outcome for cervical pain or dysfunction: a systematic review. Spine (PhilaPa 1976). 2002 Mar 1;27(5):515-22. DOI: $10.1097 / 00007632-200203010-00012$

20. Vermon $H$, Mior S. The Neck Disability Index: a study of reliability and validity. Journal of manipulative and physiological therapeutics. 1991,14(7):409-15. 
21. Wheeler $A H$, Goolkasian $P$, Baird AC, Darden BV. Development of the Neck Pain and Disability Scale: Item Analysis, Faces and CriterionRelated Validity. Spine;24(13):1290, July 1, 1999. DOI: 10.1097/00007632-19990701000004

22. Menezes EM, Rocha RO, Moreira AAD, Nascimento DG, Araújo AEP, Maia LCS. Artroplastia total do disco cervical com prótese de Bryan. Resultados Clínicos e funcionais. Rev Coluna/Columna. São Paulo, 2012; 11(3): 2148.

23. Moffett JAK, Jackson DA, Richmond R, Hahn S, Coulton S, Farrin A, et al. Randomised trial of a brief physiotherapy intervention compared with usual physiotherapy for neck pain patients: outcomes and patient's preference. BMJ 2005; 330-75.

24. Fejer R, Jordan A, Hartvigsen J. Neck pain and disability due to neck pain: what is the relation? Eur Spine J. 2008; 17:80-88. DOI: 10.1007/ s00586-007-0521-9

25. Ferreira ML, Borges $B M$, Rezende $I L$, Carvalho LP, Soares LP, Dabes RA, Carvalho G, et al. Are neck pain scales and questionnaires compatible with the international classification of functioning, disability and health? A systematic review. DisabilRehabil. 2010; 32 (19):1539-46. DOI: $10.3109 / 09638281003611045$

26. Pickering PM, Osmotherly PG, Attia JR, McElduff $P$. An examination of outcome measures for pain and dysfunction in the cervical spine: a factor analysis. Spine (Phila Pa 1976). 2011 Apr 1; 36 (7):581-8. DOI: 10.1097/ BRS.0b013e3181d762da

27. Kathleen N. L. Assessing health status and quality-of-life instruments: attributes and review criteria. Scientific Advisory Committee of Medical Outcomes Trust. Quality of life research. Amsterdan, 2002; 11:193-205.

28. Soares E, Serrano A, Guralnick MJ. Tradução, adaptação e validação do conteúdo da secção I da Escala: "Assessment of peer relations" para o idioma português. Journal of Human Growth and Development, 2013; 23(1): 31- 40.

29. Sardinha A, Levitan MN, Lopes FL, Perna G, Esquivel G, Griez EJ, et al. Tradução e adaptação transcultural do Questionário de Atividade Física Habitual. [acesso em ago 2014]. Disponível: http://www.hcnet.usp.br/ipq/revista/vol37/n1/ 26.htm

30. Sani AIM. As crenças, o discurso e a acção: as construções de crianças expostas à violência interparental. Tese de doutorado, Universidade do Minho, Braga, 2003.

31. Moretti F, Zambon F, Oliveira G, Behlau M. Equivalência cultural da versão brasileira da Voice Sympton Scale: VoiSS. J Soc Bras Fonoaudiol. $2011 \mathrm{Dec} ; 23(4): 328-400$. DOI: $10.1590 /$ S2179-64912011000400018
32. Forestier R, Françon A, Arroman FS, Bertolino C. French version of the Copenhagen Neck Functional Disability Scale. Joint Bone Spine. 2007 Mar; 74 (2):155-9. Epub 2006; Jul 14. DOI: $10.1016 / \mathrm{j} . j$ bspin.2006.03.002

33. Misterska E, Jankowski R, Glowacki M. Crosscultural adaptation of the Neck Disability Index and Copenhagen Neck Functional Disability Scale for patients with neck pain due to degenerative and discopathic disorders. Psychometric properties of the Polish versions. BMC Musculoskelet Disord. 2011 Apr 29;12:84. DOI: $10.1186 / 1471-2474-12-84$

34. Kose G, Hepguler S, Atamaz F, Oder G. A comparison of four disability scales for Turkish patients with neck pain. Journal of Rehabilitation Medicine. 2007 May; 39 (5): 358362. DOI: $10.2340 / 16501977-0060$

35. Cruciani F, Adami F, Assunção NA, Bergamaschi DP. Equivalência conceitual de itens e semântica do Pysichal Activity Checklist Interview (PACI). Cad. Saúde Pública, Rio de Janeiro, 2011 Jan; 27(1):19-34.

36. Schellingerhout JM, Heymans MW, Verhagen AP, Vet HC, Koes BW, Terwee CB. Measurement properties of translated versions of neckspecific questionnaires: a Systematic review. BMC Medical Research Methodology. 2011; 11:87. DOI: $10.1186 / 1471-2288-11-87$

37. Falavigna A, Telles AR, Braga GL, Barazzetti BO, Ongaratto $D$, Lazzaretti $L$, et al. Instrumentos de avaliação clínica e funcional da coluna vertebral. Ver Coluna/Columna. São Paulo, 2011; 10(1): 62-7. DOI: 10.1590/S180818512011000100012

38. Canto FRT, Santos Neto PR, Castro IJC, Canto RST, Santos HA, Nascimento MVM. Avaliação radiológica e funcional dos pacientes com fratura da coluna cervical subaxial. Rev Coluna/ Columna. São Paulo, 2009; 8(4):381-385. DOI: 10.1590/S1808-18512009000400006

39. Cleland JA, Childs JD, Whitman JM. Psychometric Properties of the Neck Disability Index and Numeric Pain Rating Scale in Patients With Mechanical Neck Pain. Archives of Physical medicine and Reabilitation.vol 89, 2008 Jan;6974. DOI: $10.1016 / j$.apmr.2007.08.126

40. Misailidou $V$, Malliou $P$, Beneka A, Karagiannidis A, Godolias G. Assessment of patients with neck pain: a review of definitions, selection criteria and measurement tools. Journal of Chiropractic Medicine. 2010; 9:49-59. DOI: 10.1016/ j.jcm.2010.03.002

41. Moffett JAK, Jackson DA, Richmond R, Hahn S, Coulton S, Farrin A, et al. Randomised trial of a brief physiotherapy intervention compared with usual physiotherapy for neck pain patients: outcomes and patient's preference. BMJ 2005; 330-75. 


\section{RESUMO}

Introdução: o questionário dinamarquês intitulado The Copenhagen Neck Functional Disability Scale (CNFDS) é um instrumento de autoavaliação de queixa cervical originalmente desenvolvido no idioma inglês e que não existe, até esse momento, sua tradução para o português brasileiro. O processo envolvido nessa pesquisa se mostrou relevante para a exploração do questionário e realização dos ajustes necessários para que esse seja funcional e aplicável na Língua e Cultura Portuguesa Brasileira. Portanto, uma vez sido feito isso, profissionais da saúde poderão se beneficiar dessa versão em sua prática clínica. Objetivo: realizar a tradução e adaptação cultural para o português brasileiro da escala funcional de incapacidade do pescoço de Copenhagen (The Copenhagen Neck Functional Disability Scale - CNFDS). Método: o questionário em questão foi traduzido para a língua portuguesa brasileira por dois fisioterapeutas brasileiros e fluentes na língua portuguesa e inglesa. A retrotradução foi realizada por uma terceira pessoa, brasileira, bilíngue e professora de inglês, não participante da etapa anterior. Após comparação das traduções produziu-se uma única versão traduzida, denominada Escala Funcional de Incapacidade do Pescoço de Copenhagen (EFIPC) sendo que, em cada questão foi acrescentada a opção "não se aplica" na chave de resposta. No processo de tradução e adaptação cultural não houve modificação e/ou eliminação de nenhuma questão. Resultado: a composição da Escala Funcional de Incapacidade do Pescoço de Copenhagen reflete a versão original em inglês, ou seja, com um total de 15 questões, sendo que as questões de número 1 a 5 apresentam direção de resposta positiva (resposta "sim" indica uma boa condição cervical), e as questões de número 6 a 15 apresentam direção de resposta negativa (resposta "sim" indica uma má condição cervical). Conclusão: o processo envolvido nessa pesquisa permitiu atingir o objetivo desejado e, assim, foi possível traduzir e adaptar culturalmente para o português brasileiro o conteúdo do questionário CNFDS, dando origem à escala funcional de incapacidade do pescoço de Copenhagen.

Palavras-chave: dor no pescoço, incapacidade, fisioterapia, tradução. 